\title{
Defining Digital Game-Based Learning for Science, Technology, Engineering, and Mathematics: A New Perspective on Design and Developmental Research
}

Shahrul Affendi Ishak ${ }^{1}$, BAA, MA; Rosseni Din ${ }^{1}$, AAD, BSc, MEd, PhD; Umi Azmah Hasran² ${ }^{2}$ BSc, MSc, PhD

${ }^{1}$ Science, Technology, Engineering, and Mathematics Enculturation Research Centre, Faculty of Education, Universiti Kebangsaan Malaysia, Bangi, Malaysia

${ }^{2}$ Fuel Cell Institute, Universiti Kebangsaan Malaysia, Bangi, Malaysia

Corresponding Author:

Rosseni Din, AAD, BSc, MEd, PhD

Science, Technology, Engineering, and Mathematics Enculturation Research Centre

Faculty of Education

Universiti Kebangsaan Malaysia

43600 UKM

Bangi, 43600

Malaysia

Phone: 60166656420

Email: rosseni@ukm.edu.my

\begin{abstract}
In the modern age, digital games are widely used as informal media for Science, Technology, Engineering, and Mathematics (STEM) education and medical therapy for game-based learning. Digital games provide learners with a graphical system of interaction that enhances scientific concepts within an enjoyable environment. The vastly increasing number of digital games produced in the market affects the quality of STEM digital games while requiring multidisciplinary expertise. This paper proposes a framework for STEM digital game-based learning encompassing input-process-output stages. Several studies from the early 2000s onward were reviewed to discuss and present a new perspective on a framework for the design and development of digital games, particularly for STEM. This proposed framework consists of digital game development as input, experience as a process, and constructs as output. This simple and precise framework will generate a universal product for various types of learners. It can thus be used as a guideline for game designers, developers, and experts to develop STEM digital games and achieve better learning outcomes.
\end{abstract}

(J Med Internet Res 2021;23(2):e20537) doi: 10.2196/20537

\section{KEYWORDS}

digital game-based learning; STEM digital game; game development model; game design; design and developmental research

\section{Introduction}

The use of digital games for education has been identified as one of the global pedagogical approaches required for $21 \mathrm{st}$ century learners [1]. The intention is to make STEM (science, technology, engineering, and mathematics) education more interactive and interesting and enhance understanding of STEM concepts [2,3]. Individuals in any age range can learn through digital games. Ultimately, it is more practical to use such games in kindergarten to grade 12 education (primary and secondary school) to increase students' levels of interest in STEM. An interactive gaming system uses advanced graphics and programming tools. STEM content can be gamified easily in the current digital era. Game designers and developers often collaborate with teachers and experts to construct good instructional games for STEM learning as a universal product. This type of pedagogical approach is known as digital game-based learning [4] or STEM digital game-based learning $[5,6]$.

Using digital games to enhance STEM education is important. Their purpose is to allow scientific concepts to be visualized [7-9]. The STEM curriculum consists of multiple facts and concepts learners should understand and practice in their daily lives. Some may not be easy to learn using conventional teaching pedagogy [10]. Teachers need supporting learning material to visualize each concept, for which digital games can be the best 
tools. Digital games allow learners to interact with game mechanics in a virtual world, achieving the set goals as a result of the desire to win triggered by these games. This makes learners feel enjoyment while simultaneously enabling them to gain a better understanding of STEM content. Their interaction and involvement in experiencing and understanding the game while resolving problems in the virtual world provide a meaningful gaming experience [2,8,9]. Thus, the use of digital games not only enhances learning, develops skills, and increases the memorization and understanding of STEM, it also helps to maintain interest and create a STEM mindset [11].

Digital games for formal and informal education are accessible through computers, tablets, and smartphones, all of which are popular among digital natives-the new digital generation [12]. STEM education is challenging for young people. Most digital games aim to enhance STEM learning on various gaming platforms [13]. This was introduced in the earliest model of game-based learning developed by Garris et al [13], which consisted of input, process, and output (Figure 1). Current studies on gaming and learning have 3 major and distinct perspectives-(1) research on input: how to develop educational digital games; (2) research on process: how the games work for users; and (3) research on outcome: impact of the games. Advancing gaming technology means the number of digital games keeps increasing, and developers are competing with each other [14]. Developing digital games for STEM involves a multitude of team experts. These collaborations lead to an agile form of development that requires multiple lightweight processes over a shorter period. This makes it easier for each game designer, game developer, and STEM expert to ensure the digital game undergoes a systematic development process suitable for STEM digital game-based learning.

Figure 1. Input-process-output model adapted by Garris et al [13].

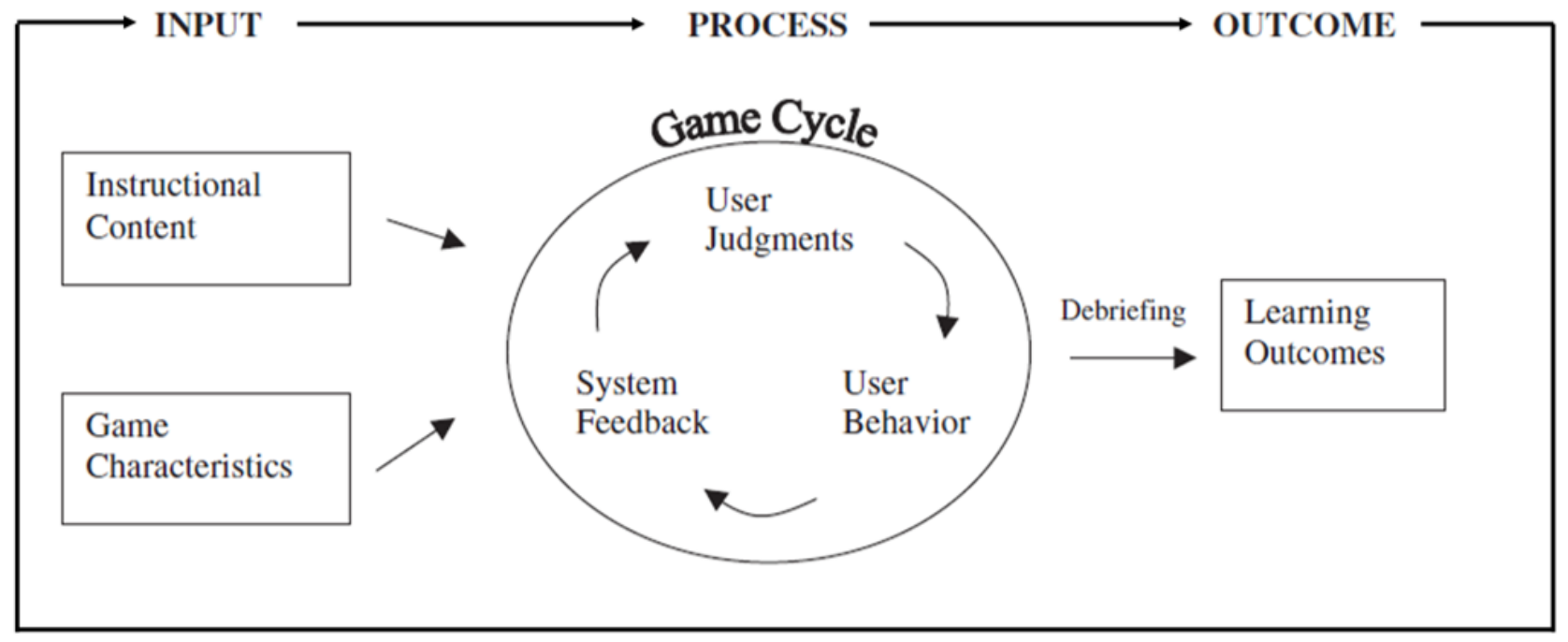

Game development processes are integrated and mapped into the design and development research, with emphasis on a systematic process of product development to achieve STEM learning outcomes. Digital game development undergoes iteration processes. From an industrial perspective, this involves preproduction, production, and postproduction phases as a linear process (Figure 2) [15]. However, studies [16-25] involving design and development research indicate that research products should undergo iteration processes until the development objective is achieved. Thus, digital games must be created for use by numerous people regardless of their abilities and demographic characteristics. This concept is synonymous with personalized learning based on a universal design for learning $[16,17]$. From an educational perspective, digital games are viewed as a learning tool in which STEM content is important in ensuring each game enhances learning and interest in STEM. Although previous studies [2,4,5,8,10,12,13,26-32] have introduced various models of digital game-based learning for specific outcomes, they have not described the development input-process-output structure as a holistic framework.
In the fourth industrial revolution environment, daily human activities have been influenced by digital technology. The new digital generation play digital games as part of their leisure activities. Numerous studies [26,27] on digital games have been conducted over the past two decades and have had a major influence on individual learning process; however, they have rarely discussed STEM learning. Because the number of digital games for STEM keeps increasing as a result of rapid development by the gaming industries, a relevant theoretical and practical underpinning of the development process for better STEM learning outcomes is required. As a universal product, the use of digital games for STEM does not rely on achieving better learning outcomes alone, it also needs to stimulate young people's interest in STEM as a future career from an early age. Thus, this paper proposes a framework to understand STEM digital game-based learning encompassing design and development, gaming experience, and the generation of STEM outcomes. 
Figure 2. Game development process from industrial practice.
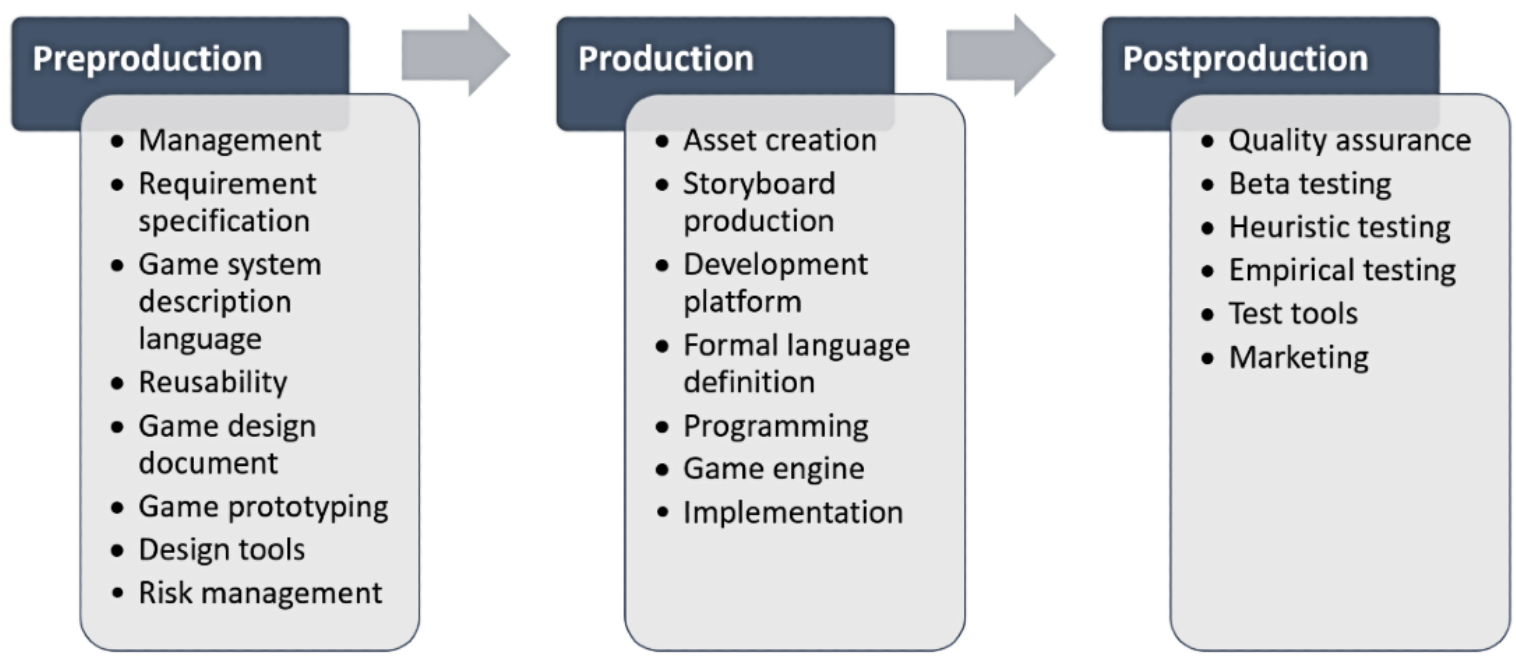

\section{Digital Game-Based Learning for STEM}

Discussions on the use of digital games for STEM can be confusing. It is a multidisciplinary field consisting of 2 different domains: STEM education and digital gaming. The link between these fields triggers the need for further research to understand how and why digital games affect STEM learning. Thus, the use of digital games and STEM learning should be studied in parallel. Digital game-based learning for STEM is also a difficult concept to define. In terms of their separate fields, digital game-based learning is defined as the use of digital games to enhance learning. Thus, to develop a more holistic perspective, we define STEM digital game-based learning as the process of creating an interactive STEM environment through digital games to enhance individual STEM learning. As such, several relevant design and development studies are now reviewed.

Most of the development models for any product undergo a systematic process. Several studies proposed a new model adapted from the original ADDIE (Analysis, Design, Development, Implementation, and Evaluation) model $[20,33,34]$. Din [18] revealed that the ADDIE model did not consist of a usability test, which is the most important process in product development. Other scholars have also adapted and improved the model to ensure a better systematic process $[20,33,34]$; however, in the context of developing a digital game, every process undergoes rapid and, some may argue, agile development. This is due to the higher number of digital games produced each day. Gaming industries tend to develop digital games in a shorter time, and some might not follow the systematic process proposed by the literature. This increases the number of low-quality digital games for users.

Din initially developed the Model Pembangunan Sistem to design and create a computer conferencing system [18] and further developed the model into Model RekaBangun Sistem Pengajaran dan Pembelajaran [19] after testing it in the development and validation of integrated meaningful hybrid e-training for computer science-a theoretical- and empirical-based design and development approach [20]. This model was tested in numerous other studies to generate the fourth version, the Model RekaBangun Sistem Pengajaran dan
Pembelajaran IV now called the Model RekaBangun SPP IV [19]. Between 2011 and 2015, Din et al [16] rigorously tested the model and developed the Universal Design for Learning Instructional Design model. Between 2015 and 2020, Din combined this model with a simpler agile version of the Model RekaBangun SPP IV after rigorous testing on more than 15 online and mobile modules, systems, and apps [17]. This final and latest version comes complete with a universal design for learning and agile development method and contains modeling stages with value integration [17,21].

\section{Input as Digital Game Development}

In digital game design, designers first identify the input elements. Universal design ensures a high degree of usability and accessible digital games for various types of learners regardless of ability [28,35,36]. Several models have been analyzed and proposed to determine which specific attributes are needed. A game perspective emphasizes content and game characteristics for enjoyment, while educational technology emphasizes learning content and a pedagogical approach. The combination of these 2 perspectives produces a better attribute as input for the game design system.

Gamification is well-known in educational technology as defining the process of integrating learning content into game mechanics [37]. The purpose is to make the learning content more interesting and engaging and to motivate learners throughout all elements of game-design [38]. Studies $[6,13,17,19,22,28-30,39,40]$ indicate that several universal design attributes need to be incorporated into educational games such as learning theory, learning strategy, pedagogy, learning content, and game characteristics such as value integration. For STEM digital games, STEM learning content is a more suitable term representing the learning content attribute. All these attributes are subsequently included in the game design system.

Input for digital game development requires several attributes to undergo systematic development processes. These are integrated from digital games and education perspectives [17,19,30,39-43]. Din's early development model [18-20] did not separate instructional design from the development model. Instead, instructional design processes were embedded into 
phases of development [19]. After 2015, Din extracted instructional design components from the development phases. This yielded 2 separate models, the instructional design model (Eclectic Universal Design for Learning model) presented in Figure 3 and the development model presented in Figure 4 $[17,44]$. The learning design is inspired by the universal design for learning model. It represents the expansion of phase 1 through phase 3 of the development model. The original model consisted of 4 main components: (1) eclectic learning theory, (2) eclectic content, (3) eclectic pedagogy, and (4) eclectic learning strategy.

Figure 3. Eclectic Universal Design for Learning model.

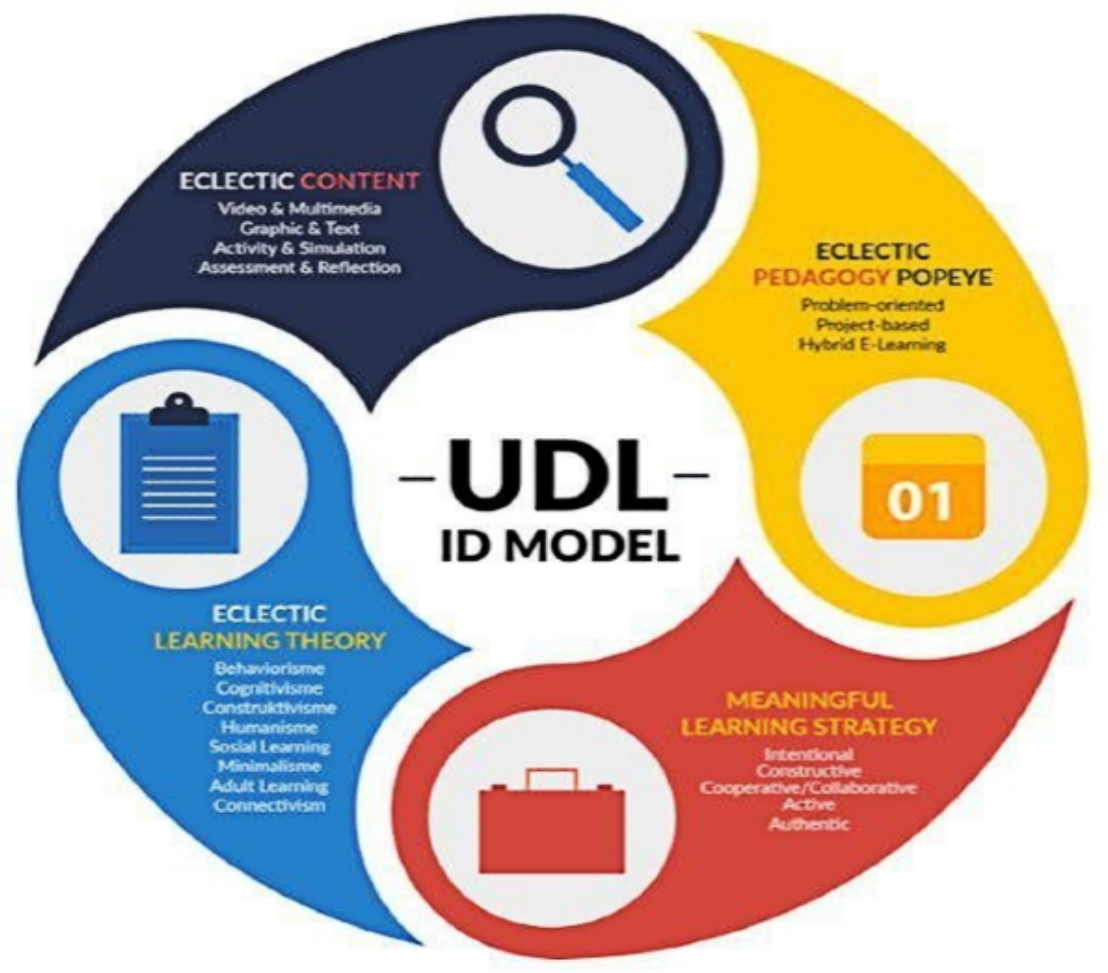


Figure 4. The development model $[44,45]$.

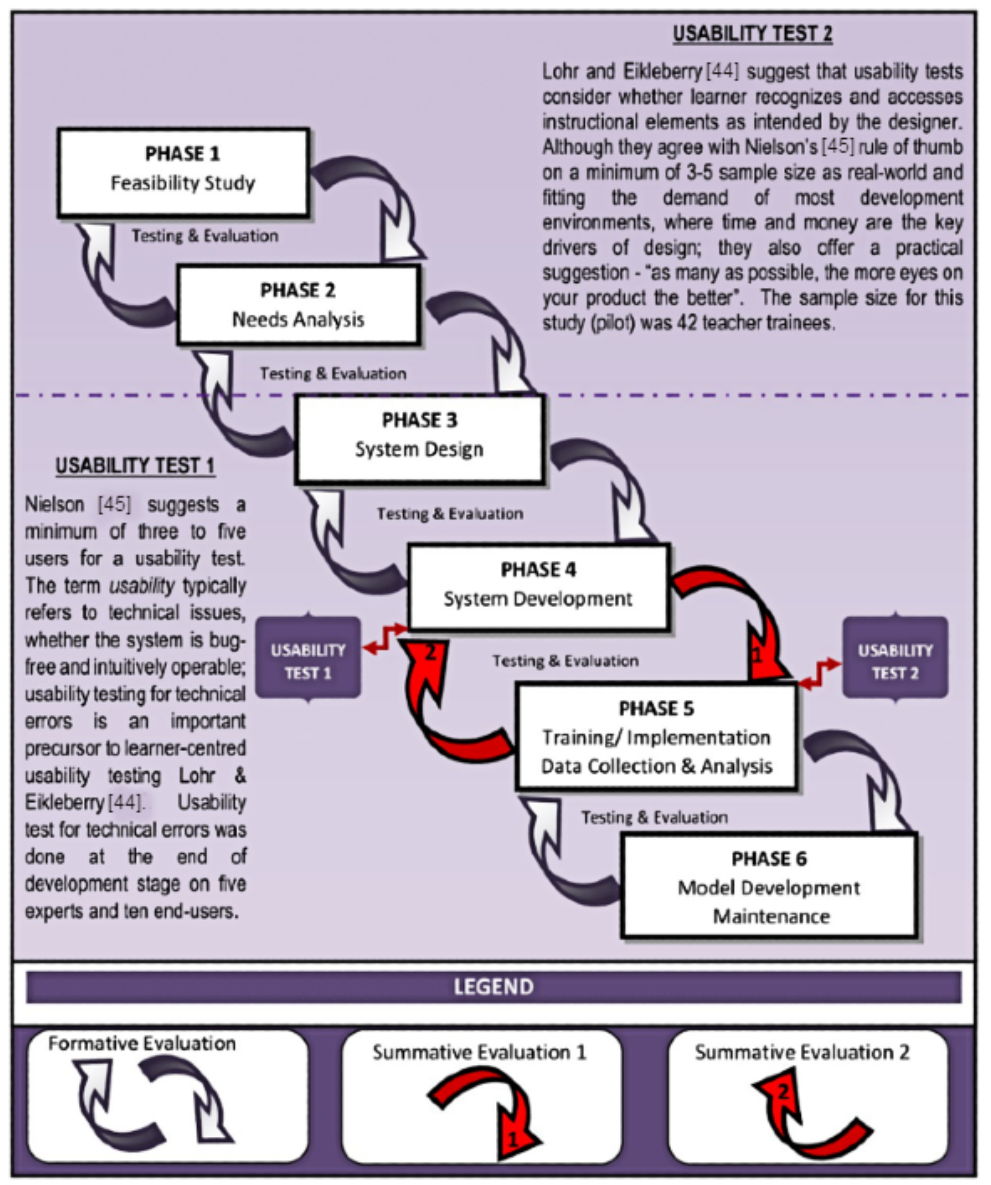

The agile version $[17,46]$ of the integrated model for the instructional design, development, and modeling of a personalized learning environment in education, namely the UDin model, is presented in Figure 5 [46]. According to Din, the UDin model, which is a 20-year transformation model of the design, development, and modeling of a learning system, added the taken-for-granted Learning Outcome component. This was aligned with the Assessment component and both were placed in the center as the innermost part of the model labeled Learning Outcome and Assessment [17,46]. The model emphasizes continuous assessment. The rubrics are mainly used as assessment tools. The assessment methods range from gamification, reflection, and visual-, video- and technology-mediated communication to field work $[17,46]$. Din's previous work discusses the assessment method and tools in detail; this encompasses studies by Din et al [23-25,47], Azizul and Din [48], Batainah et al [49], Salleh et al [50], and Abdul Manaf et al [51]. Conventional quizzes transformed into interactive online quizzes are also used as formative evaluation alternatives in online modules. Some courses also retain the pen-and-pencil test, primarily for final summative evaluation. 
Figure 5. The final UDin model—2 decade transformation of the design, development, and modeling of a learning system.

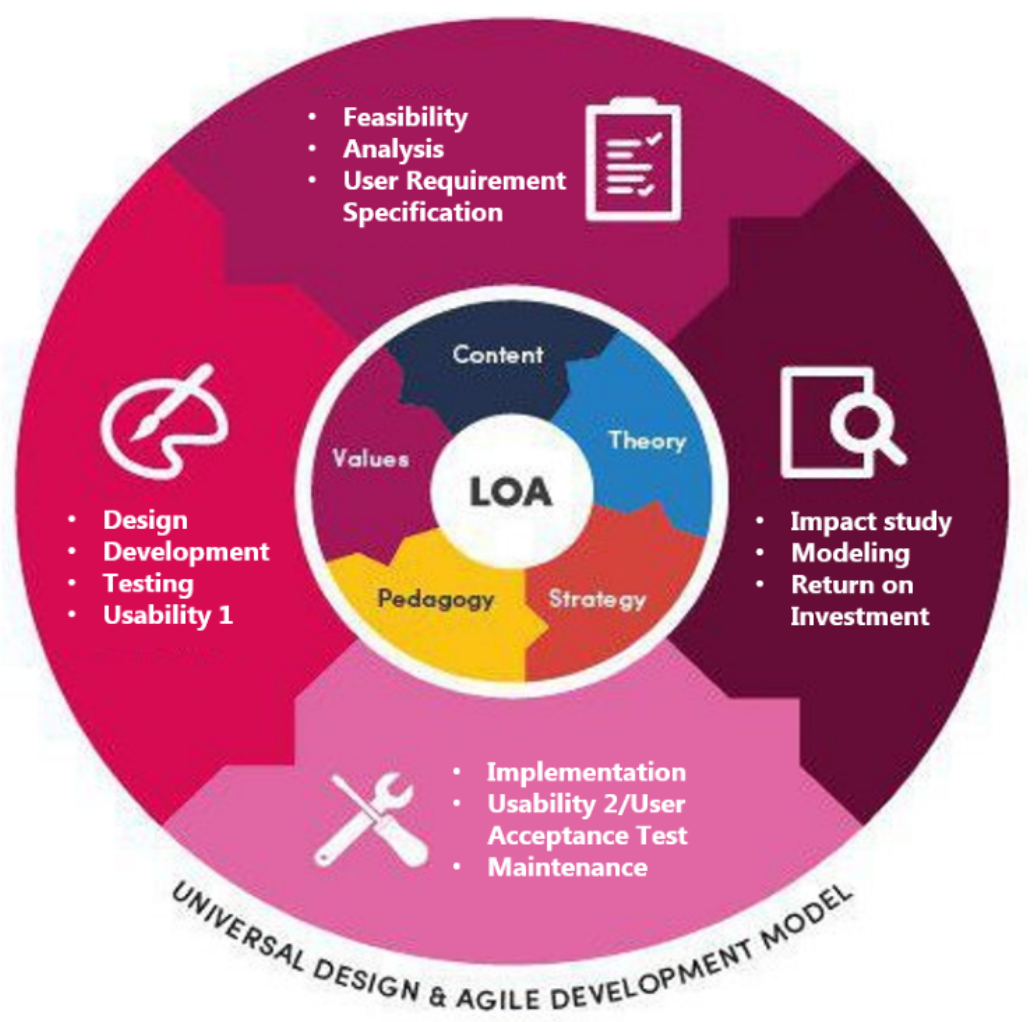

The simplified version of the STEM digital game development process is presented in Figure 6. As a product for research purposes, the framework consists of 5 main phases: conception phase, design phase, prototyping phase, analyzing phase, and evaluation phase. The conception phase starts with the feasibility of the proposed idea or game concept. Research needs to be undertaken by the developer or game designer to ensure the novelty of the idea compared with existing games. The game developer and STEM experts must therefore examine, analyze, and discuss the main concept of the game that needs to be developed. All 5 components of the universal design for learning mentioned in the input session adapting the UDin model $[17,46]$ are followed in this conception phase. The adapted universal input attributes are learning theories, learning strategy, pedagogy, STEM learning content, and game characteristics. These are gamified into the mechanics of the game. Analysis of user requirement specifications ensures the game has a targeted audience. All discussion regarding the concept is contained in a game specification document that consists of team members, targeted users, game theme, game platform, game mechanics, and game concept. 
Figure 6. Proposed STEM digital game development process.

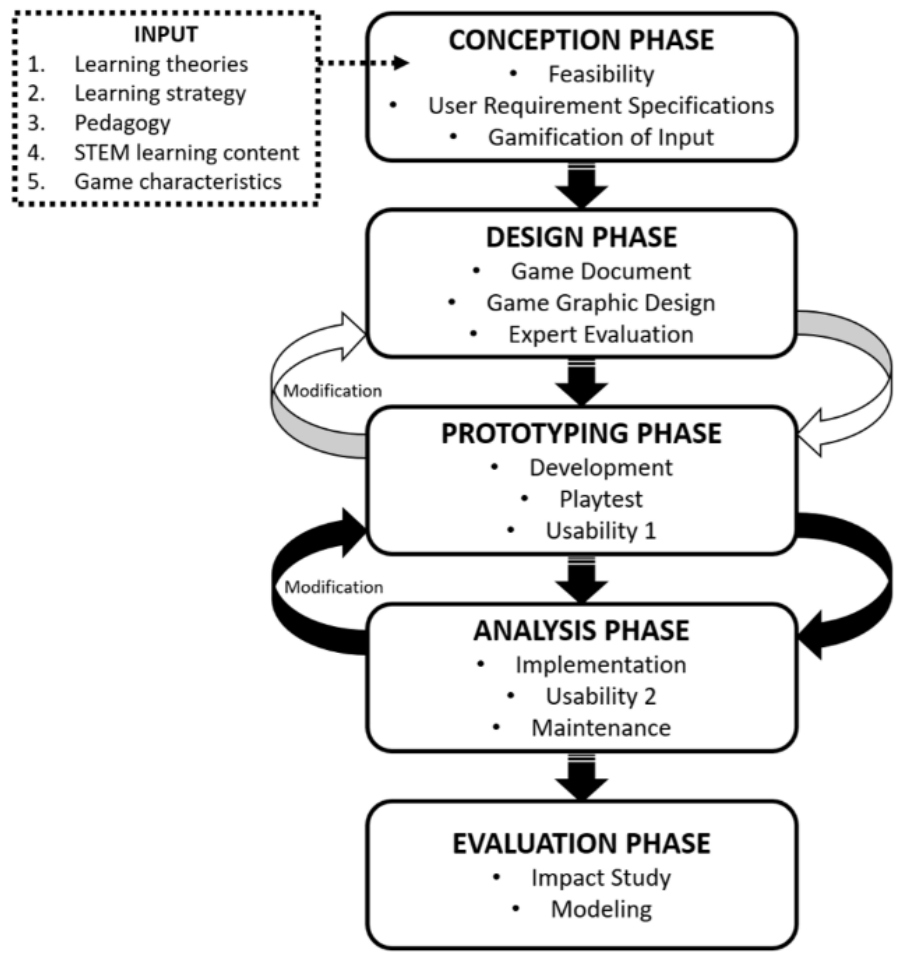

The integration of input through gamification relies on theory. In the proposed model (Figure 6), learning theories serve to frame the context of STEM digital games. Several theories have been associated with digital game-based learning. However, to purposefully create STEM digital games for STEM education, 3 major learning theories have been identified: the theory of experiential learning, theory of self-determination, and the educational-psychology theory of interest development. Blending these theories with a learning strategy, pedagogy, STEM learning content, and game characteristics generates a holistic universal attribute to produce one digital game underlying learning and game development perspectives. The important element in creating STEM digital games is the integration of STEM content. This attribute plays a major role in characterizing STEM digital games. Next, the development of game graphic design is designed based on game specification document and later must to be evaluated by experts.

The prototyping phase is one in which the design and development of the digital games begins. The identified input attributes are ready for the graphics and programming process. All attributes act as an underlying basic or game design in a form of system and mechanics. To program the game system, game designers and programmers follow user-need specifications for the game design. The first prototype of the designed digital games undergoes a playtest among team members prior to a small-scale usability test with a targeted audience. This is to ensure that the digital game works without any major errors. Comments at this point are recorded for improvement. The prototyping phase continues with Usability Test 1 comprising a targeted audience of 3 to 5 users [45]. The games are then modified and improved based on the results.
The next phase is the analysis phase, in which the game is ready for large-scale testing. This consists of Usability Test 2, and all comments are recorded. However, if the result shows another emerging error, the game needs to undergo another prototyping phase so that improvements can be made. The development team need to ensure the iteration process between the prototyping and analysis phases meets the dateline and cost requirements. After the game is tested and data are collected, the programmer makes final improvements during the maintenance phase. The final phase is the evaluation phase in which the performance of the digital game is assessed. The evaluation measures the relevant constructs involved. It also determines whether the game has achieved the objective of development. Due to budget problems, the evaluation process sometimes starts simultaneously with Usability Test 2 [19,22]. In such cases, Usability Test 2 is conducted with a larger targeted audience so that evaluation can be performed at the end of the test.

\section{Process as Experience}

User experience is one of the main components of using digital games in STEM education. During testing, there are interactions among users. Users enter the game cycle and make judgements based on observations to understand the system during the first attempt. The behavior of the game provokes the user to try what they have observed regarding the interactions taking place in the game system. The trial-and-error process allows formulation of a meta-framework of conceptual understanding as to how the system works in the developed digital game. The system feedback offered by the digital game due to the designed rules enables users to understand when certain actions do not produce 
the correct outcome. The cycle occurs continuously while users remain in the gaming world system.

The game cycle and STEM education are related. STEM education emphasizes the need for scientific thinking [11,52,53]. The digital game thus stimulates scientific thinking via observation (understanding how the game system works at the first attempt as a form of assumption), testing (making predictions and testing the assumption as a form of action), and drawing conclusions (system feedback shows whether the action performed produces the current movement inside the game). This game cycle provides the experience of engagement and involvement in an enjoyable environment. At the same time, the digital game helps users practice scientific skills without even realizing they are doing so.

\section{Output as Constructs Involved}

There are several constructs involved when the user plays and interacts with the developed digital game. The constructs relate to the main objective of the digital game, which is designed according to STEM purposes. Research shows that any digital game provokes learning due to interaction via the game cycle, investigating the relationship between those constructs. Based on a review of literature, this paper identifies 4 major constructs:(1) digital game, (2) scientific concept, (3) meaningful gaming experience, and (4) interest in STEM (Figure 7). Figure 7 also indicates that the digital game influences interest in STEM through the presence of scientific concepts and meaningful gaming experience as mediators. The major constructs proposed in this paper need to be measured to produce the structural model and measure the effectiveness of STEM digital games.

Figure 7. Proposed relationship of the constructs involve by using digital game.

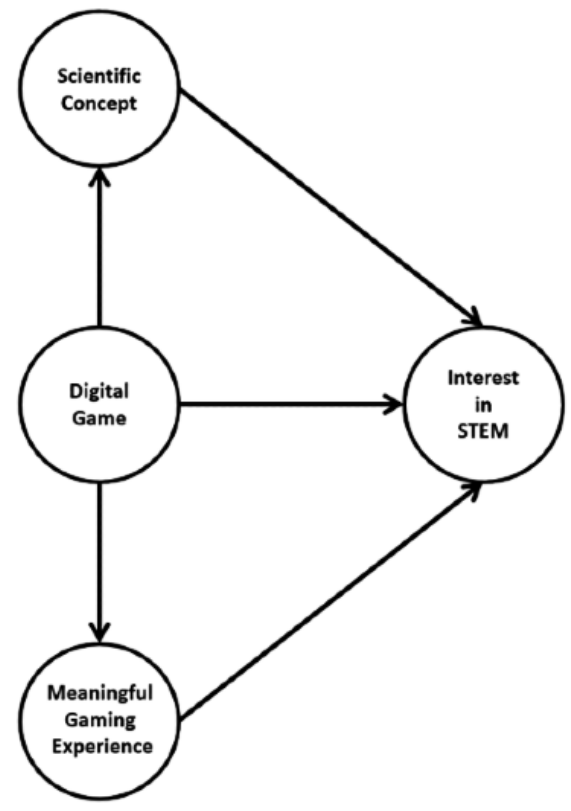

To determine this relationship, several studies $[2,9,11,31,32,54-79]$ were reviewed and the result mapped into one framework, as depicted in Figure 7. Because the data and results presented are scattered, this model purposely maps the result into the context of STEM digital games (Table 1). Based on the common findings, the digital game has a strong relationship with learning outcomes as the formation of scientific concepts is based on the game content. At the same time, research on digital games as entertainment also reveals a relationship with the gaming experience as the player feels a strong connection with the character inside the game world. However, Fisher [11] and other information sources
$[1,2,8,9,12,26,27,55-58,79]$ from the internet claim that the use of a digital game is the best pedagogical approach to increase or stimulate STEM interest among individuals. Digital games may therefore affect individual psychology in that the experience of playing is related to an interest in STEM. This relationship has been confirmed by Krapp [72] where individual interest is a process that undergoes 4 stages [72]. Providing STEM digital games is one of the practices based on Krapp's concept of interest development. According to the literature, stimulating STEM interest using digital games is not a direct cause-effect relationship as another 2 variables have been identified as mediating this effect. 
Table 1. Summary of research findings on the relationship between potential constructs as output for STEM digital games.

\begin{tabular}{|c|c|c|}
\hline Variables & Findings & References \\
\hline Digital games $\rightarrow$ scientific concepts & $\begin{array}{l}\text { Digital games are potential tools for teaching STEM }{ }^{\mathrm{a}} \text { concepts via a specific topic. } \\
\text { Knowledge gains underlie the gameplay. The integration of scientific content acts as a } \\
\text { vehicle for gameplay. Most players exhibit higher knowledge gain, as a STEM learning } \\
\text { outcome, using digital games. The target group, with the most potential for STEM digital } \\
\text { games, is children. }\end{array}$ & {$[9,31,32,54-61]$} \\
\hline $\begin{array}{l}\text { Digital games } \rightarrow \text { meaningful gam- } \\
\text { ing experience }\end{array}$ & $\begin{array}{l}\text { Playing digital games provides a gaming experience. As part of edutainment, good digital } \\
\text { games create meaningful experiences for players. Players with a higher level of game } \\
\text { experience and feedback engage in a more in-depth reflective process. Players will feel } \\
\text { the fun element and have strong connections with the character played inside the game } \\
\text { world. }\end{array}$ & [62-69] \\
\hline Digital games $\rightarrow$ interest in STEM & $\begin{array}{l}\text { Digital media have a significant relationship with an interest in STEM. Due to better } \\
\text { gameplay, digital games might therefore be successful in increasing students' interest in } \\
\text { STEM. Studies show that using digital games may lead to a positive attitude toward } \\
\text { STEM subjects and a STEM career. }\end{array}$ & {$[2,11,55,70-72]$} \\
\hline $\begin{array}{l}\text { Scientific concepts } \rightarrow \text { interest in } \\
\text { STEM }\end{array}$ & $\begin{array}{l}\text { Knowledge gained by providing authentic scientific inquiry will trigger an interest in } \\
\text { STEM. Students who play video games will engage in a STEM subject related to their } \\
\text { lives. }\end{array}$ & {$[55,73-75]$} \\
\hline $\begin{array}{l}\text { Meaningful gaming experience } \rightarrow \\
\text { interest in STEM }\end{array}$ & $\begin{array}{l}\text { Providing digital games will serve to enhance individual curiosity. Once attracted to the } \\
\text { game, the playing process will increase the level of interest in the content gained. Because } \\
\text { a meaningful gaming experience is a product of playing digital games, studies show that } \\
\text { this factor is significantly related to an interest in STEM. }\end{array}$ & [76-79] \\
\hline
\end{tabular}

${ }^{a}$ STEM: science, technology, engineering, and mathematics.

To measure the relationship between the 4 identified variables (digital games, scientific concepts, meaningful gaming experience, and interest in STEM) simultaneously, these variables need to be defined and measured individually in the form of a measurement model. Structural equation modeling helps to measure and fit this hypothetical model with data in one go. This outcome at this stage is best achieved using smart-PLS software (SmartPLS GmbH) since it is at an exploratory stage.
The proposed STEM digital game-based learning framework is that of a linear input-process-output structure (Figure 8). This framework can be employed by any game designer, developer, or even teacher to develop a good STEM digital game with the objective of increasing STEM interest among learners. Young people with a low interest in STEM will therefore benefit from playing a STEM digital game. 
Figure 8. Proposed framework on STEM digital game-based learning.

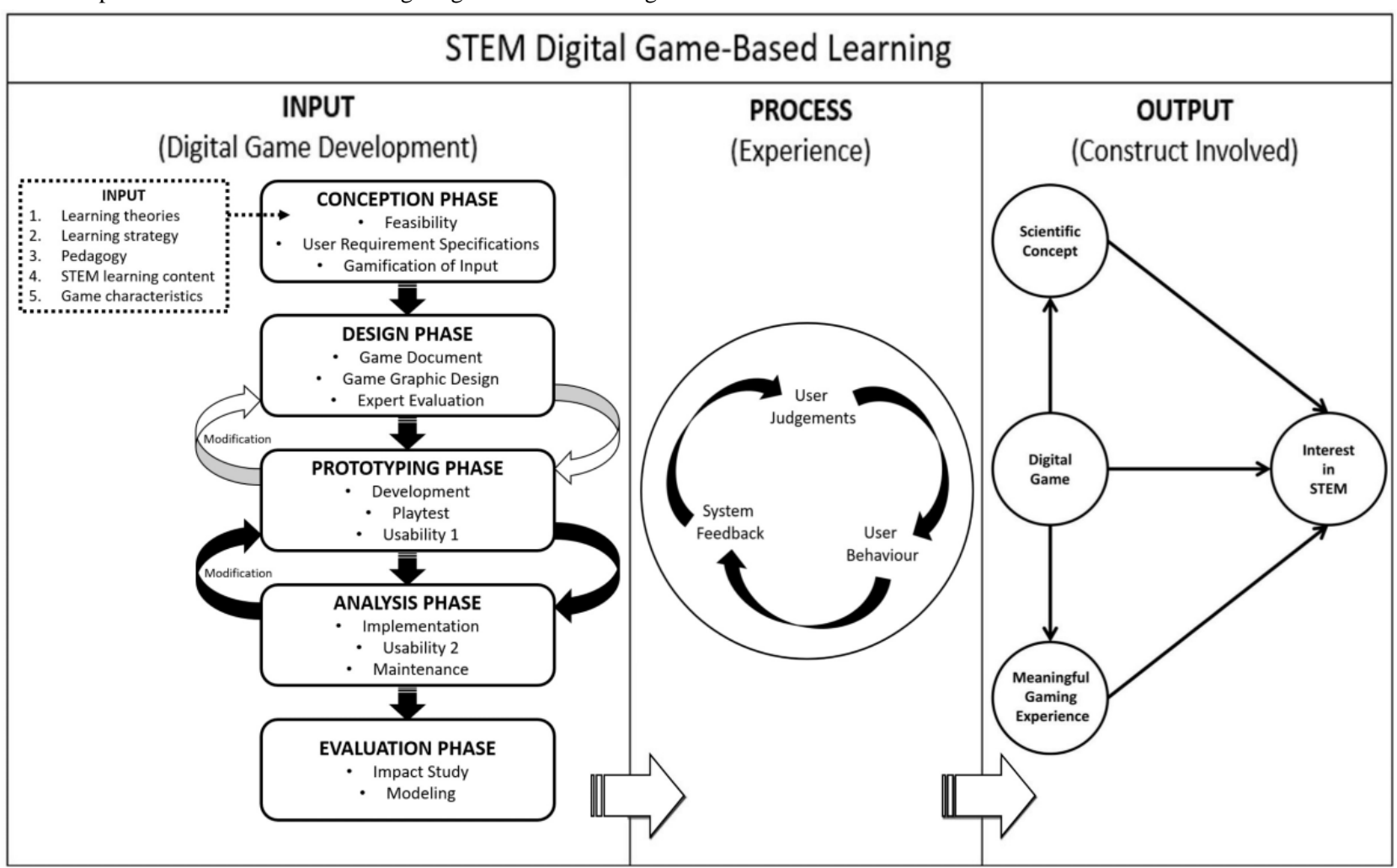

\section{Conclusion}

This paper proposes a framework for STEM digital game-based learning based on the current and vast body of gaming technology and a universal design for learning instructional design and agile development processes. Following the proposed model will enable the product to compete with what is available in a market where most developers are competing to produce digital games. However, the game needs to undergo a systematic development process as proposed. This paper thus outlined the specifications needed for a digital game to obtain the desired outcomes.

\section{Acknowledgments}

We would like to convey our utmost appreciation and thanks to all those who supported our study, especially the STEM Enculturation Research Centre (Faculty of Education, Universiti Kebangsaan Malaysia) for grants Dana Pecutan Penerbitan (GUP-2020-020 and GG-2019-046). Many thanks to all researchers under the project and the Personalized Education Research Group for financial, intellectual, spiritual, and moral support.

\section{Conflicts of Interest}

None declared.

\section{References}

1. Kukulska-Hulme A, Bossu C, Coughlan T, Ferguson R, FitzGerald E, Gaved M, et al. Innovating Pedagogy 2021: Open University Innovation Report 9. Milton Keynes: The Open University; 2021:1-51.

2. Ball C, Huang K, Cotten SR, Rikard RV. Gaming the SySTEM: the relationship between video games and the digital and STEM divides. Games Cult 2018 Nov 29;15(5):501-528. [doi: 10.1177/1555412018812513]

3. Mohtar LE, Halim L, Abd Rahman N, Maat SM, Iksan ZH, Osman K. A model of interest in stem careers among secondary school students. J Baltic Sci Education 2019 Jun 10;18(3):404-416. [doi: 10.33225/jbse/19.18.404]

4. Zendler A, Greiner H. The effect of two instructional methods on learning outcome in chemistry education: the experiment method and computer simulation. Education Chem Engineers 2020 Jan;30:9-19. [doi: 10.1016/j.ece.2019.09.001]

5. Yousof A, Abousamra N. The future of digital game-based learning (DGBL) in shaping intercultural communication competency. In: Lum HC, editor. Critical Issues Impacting Science, Technology, Society (STS), and Our Future. Hershey, PA: IGI Global; 2019:81-110.

6. Mat Sin N, Talib O, Norishah TP. Merging of game principles and learning strategy using apps for science subjects to enhance student interest and understanding. Jurnal Teknologi 2013 Aug 15;63(2):7-12. [doi: 10.11113/jt.v63.1998] 
7. Freeman B, Marginson S, Tytler R. The Age of STEM: Educational Policy and Practice Across the World in Science, Technology, Engineering and Mathematics. United Kingdom: Routledge; Nov 3, 2014.

8. Hyatt KJ, Barron JL, Noakes MA. Video gaming for STEM education. In: Yang HH, Wang S, editors. Cases on E-Learning Management: Development and Implementation. Hershey, PA: IGI Global; 2013:103-117.

9. Wu Y, Anderson OR. Technology-enhanced STEM (science, technology, engineering, and mathematics) education. J Comput Educ 2015 Jul 24;2(3):245-249. [doi: 10.1007/s40692-015-0041-2]

10. Lay A, Osman K. Developing 21st century chemistry learning through designing digital games. J Educ Environ Sci Health 2018;4(1):81-92. [doi: 10.21891/jeseh.387499]

11. Fisher C. Designing Games for Children: Developmental, Usability, and Design Considerations for Making Games for Kids. New York: Focal Press; 2015.

12. Acquah EO, Katz HT. Digital game-based L2 learning outcomes for primary through high-school students: a systematic literature review. Comput Education 2020 Jan;143:103667-103619. [doi: 10.1016/j.compedu.2019.103667]

13. Garris R, Ahlers R, Driskell JE. Games, motivation, and learning: a research and practice model. Simulation Gaming 2016 Aug 18;33(4):441-467. [doi: 10.1177/1046878102238607]

14. Richards J, Smith C. 100 Top Games Apps Made Easy. London: Flame Tree Publishing; 2013.

15. Aleem S, Capretz LF, Ahmed F. Game development software engineering process life cycle: a systematic review. J Softw Eng Res Dev 2016 Nov 9;4(1):1-30. [doi: 10.1186/s40411-016-0032-7]

16. Din R. Foreword from the chief editor: the inaugural issue of JPL. J Personalized Learning 2018 May 1;1(1):i-iii [FREE Full text]

17. Din R. Notes from the chief editor: on designing personalized learning. J Personalized Learning 2016;2(1):i-iii [FREE Full text]

18. Din R. Model Pembangunan Sistem-Pembinaan Sistem Persidangan Berkomputer: SidangKom. Malaysian Academic Library Union Catalog.: Universiti Kebangsaan Malaysia; 2001. URL: http://malcat.uum.edu.my/kip/Record/ukm. vtls000327247 [accessed 2021-01-26]

19. Din R. Pembinaan dan Permodelan Sistem Pengajaran. Bangi: Universiti Kebangsaan Malaysia; 2014.

20. Din R. Development and validation of an integrated meaningful hybrid e-training (I-MeT) for computer science: theoretical and empirical based design and development approach. ResearchGate. Bangi: Universiti Kebangsaan Malaysia; 2010. URL: tinyurl.com/32vuz9mo

21. Din R. PLS-SEM in the final phase of product and instrument development using UDIN model. 2019 Presented at: 11th International Conference of Numerical Analysis in Engineering; August 20-22; Bandar Baru Bangi.

22. Din R. Asas Pendidikan dan Kejurulatihan ICT: Integrasi Teori, Media, Teknologi dan Reka Bentuk Pembelajaran. Bangi: Penerbit UKM; 2017.

23. Din R, Othman N, Nasir M, Murat N, Alias M. 2018 Presented at: Learning Carnival and Conference; July 16; Melaka.

24. Din R, Othman N, Murat N, Alias M, Nasir M. Formative to summative in one go. 2017 Presented at: Holistic Learning Conference (Rahole); November 20-21; Kuala Lumpur.

25. Din R, Othman N, Murat N, Alias M, Nasir M. Reflection in a blog: scaffolding to formative and summative assessment. 2017 Presented at: Holistic Learning Conference (Rahole); November 20-21; Kuala Lumpur.

26. Marcelo LE, Gabriela TP, Ivana LL, Thiago TM. Mobile game-based learning in STEM subjects. In: Khosrow-Pour M, editor. Encyclopedia of Information Science and Technology, Fourth Edition. Hershey, PA: IGI Global; 2018:6376-6387.

27. Mohdjamel F, Ahmad JN, Ali MN. The needs analysis in game-based STEM module development for KSSM science teachers. Int J Recent Technol Engineering 2019 Sep 30;8(3):6622-6628. [doi: 10.35940/ijrte.c5655.098319]

28. Cunningham L, Murphy O. Embracing the universal design for learning framework in digital game based learning - a set of game design principles. Stud Health Technol Inform 2018;256:409-420. [Medline: 30371502]

29. Masrop N, Zin N. Model Reka Bentuk dan Pembangunan Perisian Pembelajaran Berasaskan Permainan Digital (PBPD). In: Mat Zain NA, Sahari@ Ashaari N, editors. Reka Bentuk dan Kebolehgunaan Sistem Multimedia. Bangi: Penerbit UKM; 2017:82-95.

30. Shi Y, Shih J. Game factors and game-based learning design model. Int J Comput Games Technol 2015;2015:1-11. [doi: $10.1155 / 2015 / 549684]$

31. Ross AM, Fitzgerald ME, Rhodes DH. Game-based learning for systems engineering concepts. Procedia Comput Sci 2014;28:430-440. [doi: 10.1016/j.procs.2014.03.053]

32. Shute VJ, Ke F. Games, learning, and assessment. In: Ifenthaler D, Eseryel D, Ge X, editors. Assessment in Game-Based Learning: Foundations, Innovations, and Perspectives. New York: Springer Science + Business Media; 2012:43-58.

33. Norizan MD, Nor Azan MZ. Reka Bentuk Permainan Digital Latihan Menulis Huruf Jawi. In: Nor Azan MZ, Noraidah SA, editors. Reka Bentuk dan Kebolehgunaan Sistem Multimedia. Bangi: Unuversiti Kebangsaan Malaysia; 2017:63-81.

34. Kirkley SE, Tomblin S, Kirkley J. Instructional Design Authoring Support for The Development of Serious Games and Mixed Reality Training. 2005 Presented at: Interservice/Industry Training, Simulation and Education Conference (I/ITSEC); December 6-9; Orlando, Florida.

35. Jurva H. Could universal design help more students learn from games? Games and learning. 2015 Aug 13. URL: https:/ /www.gamesandlearning.org/2015/08/13/could-universal-design-help-more-students-learn-from-games/ [accessed 2020-03-28] 
36. Anderson F. How true universal design could revolutionize game development. Venture Beat. 2010 Dec 2. URL: https:/ /venturebeat.com/community/2010/12/02/how-true-universal-design-could-revolutionize-game-development/ [accessed 2020-03-28]

37. Tan WH. Gamifikasi dalam Pendidikan: Pembelajaran Berasaskan Permainan. Tanjong Malim: Penerbit Universiti Pendidikan Sultan Idris; 2016.

38. Rapp A, Hopfgartner F, Hamari J, Linehan C, Cena F. Strengthening gamification studies: current trends and future opportunities of gamification research. Int J Hum Comput Stud 2019 Jul;127:1-6. [doi: 10.1016/j.ijhcs.2018.11.007]

39. Ak O. A game scale to evaluate educational computer games. Procedia - Soc Behav Sci 2012;46:2477-2481. [doi: 10.1016/j.sbspro.2012.05.506]

40. Mat Zin NA, Yue WS. Design and evaluation of history digital game based learning (DGBL) software. J Next Generation Inf Technol 2013 Jun 30;4(4):9-24. [doi: 10.4156/jnit.vol4.issue4.2]

41. Pulsipher L. Game Design-How to Create Video and Tabletop Games, Start to Finish. North Carolina: McFarland \& Company Publisher; 2012.

42. de Byl P. Holistic Mobile Game Development with Unity. New York: Routledge; 2014.

43. Mildner P, Stamer N, Effelsberg W. From game characteristics to effective learning games. 2015 Presented at: Serious Games: First Joint International Conference; June 3-4; Huddersfield, UK p. 51-62. [doi: 10.1007/978-3-319-19126-3_5]

44. Lohr L, Eikleberry C. Learner-centered usability. tools for creating a J learner-friendly instructional environment. Performance Improvement 2001 Apr;40(4):24-27. [doi: 10.1002/pfi.4140400406]

45. Nielson J. Usability Engineering. University of Minnesota, US: Academic Press; 1993.

46. Din R. Notes from the chief editor: on universal design and agile development. Journal of Personalized Learning 2020;3(1):1-7.

47. Din R, Hamdan A, Manaf SZA. Edutechnovation day to measure learning outcome for acceptable hybrid meaningful mobile learning environment. 2015 Presented at: National University Carnival on e-Learning; December 14-15; Tanjung Malim, Perak.

48. Azizul S, Din R. Teaching and learning geometry using Geogebra software via MOOC. J Personalized Learning 2016;2(1):39-50.

49. Bataniah R, Din R. Hybrid personalized Arabic language learning. J Personalized Learning 2016;2(1):57-71.

50. Manaf S, Din R. Hamdan A Pembelajaran Peribadi Melalui Teknologi ICT Abad ke-21 ke Arah Kemahiran Boleh Pindah. J Personalized Learning 2015;1(1):57-68.

51. Hamdan A, Din R, Manaf SZA. Personalized learning environment: integration of web technology 2.0 in achieving meaningful learning. J Personalized Learning 2015;1(1):13-26.

52. Breiner J, Johnson C, Harkness S, Koehler C. What is STEM? a discussion about conceptions of STEM in education and partnerships. Sch Sci Math 2012;112(1):3-11. [doi: 10.1111/j.1949-8594.2011.00109.x]

53. Bryan L, Moore T, Johnson C, Roehrig G. Integrated STEM education. In: Johnson CC, Peters-Burton EE, Moore TJ, editors. STEM Road Map: A Framework for Integrated STEM Education. New York: Routledge; 2016:23-37.

54. Herodotou C. Mobile games and science learning: a comparative study of 4 and 5 years old playing the game Angry Birds. Br J Educ Technol 2017 Feb 13;49(1):6-16. [doi: 10.1111/bjet.12546]

55. Raffety C, Prawat T, Richter J, Hamilton RF, Schelvan M, Jones P, et al. Developing Serious games to improve learning and increase interest in STEM careers for middle school students: the mice of riddle place. 2016 Presented at: Immersive Learning Research Network: Second International Conference; June 27 - July 1; Santa Barbara, CA, USA p. 132-143. [doi: 10.1007/978-3-319-41769-1 11]

56. Liu EZF, Chen P. The effect of game-based learning on students' learning performance in science learning - a case of “conveyance go". Procedia Soc Behav Sci 2013 Nov;103:1044-1051. [doi: 10.1016/j.sbspro.2013.10.430]

57. Pedersen MK, Svenningsen A, Dohn NB, Lieberoth A, Sherson J. DiffGame: game-based mathematics learning for physics. Procedia Soc Behav Sci 2016 Jul;228:316-322. [doi: 10.1016/j.sbspro.2016.07.047]

58. Sherry JL. Formative research for STEM educational games: lessons from the Children's Television Workshop. In: Blades M, Blumberg FC, Oates C, editors. Children and Digital Games. USA: Hogrefe Publishing; 2013:90-97.

59. Clark DB, Sengupta P, Brady CE, Martinez-Garza MM, Killingsworth SS. Disciplinary integration of digital games for science learning. Int J STEM Educ 2015 Feb 11;2(1):2-21. [doi: 10.1186/s40594-014-0014-4]

60. Kiili K, Ketamo H. Evaluating cognitive and affective outcomes of a digital game-based math test. IEEE Trans Learning Technol 2018 Apr 1;11(2):255-263. [doi: 10.1109/tlt.2017.2687458]

61. Lester JC, Spires HA, Nietfeld JL, Minogue J, Mott BW, Lobene EV. Designing game-based learning environments for elementary science education: a narrative-centered learning perspective. Inf Sci 2014 Apr;264:4-18. [doi: 10.1016/j.ins.2013.09.005]

62. Hou H. Integrating cluster and sequential analysis to explore learners' flow and behavioral patterns in a simulation game with situated-learning context for science courses: A video-based process exploration. Comput Human Behav 2015 Jul;48:424-435. [doi: 10.1016/j.chb.2015.02.010]

63. Kiili K, de Freitas S, Arnab S, Lainema T. The design principles for flow experience in educational games. Procedia Comput Sci 2012;15:78-91. [doi: 10.1016/j.procs.2012.10.060] 
64. Calvillo-Gámez EH, Cairns P, Cox AL. Assessing the core elements of the gaming experience. In: Bernhaupt R, editor. Evaluating User Experience in Games, Human-Computer Interaction Series. London: Springer; 2010:47-71.

65. Rogers R, Woolley J, Sherrick B, Bowman ND, Oliver MB. Fun versus meaningful video game experiences: a qualitative analysis of user responses. Comput Game J 2016 Nov 25;6(1-2):63-79. [doi: 10.1007/s40869-016-0029-9]

66. Mills DJ, Milyavskaya M, Mettler J, Heath NL. Exploring the pull and push underlying problem video game use: a self-determination theory approach. Personality and Individual Differences 2018 Dec;135:176-181. [doi: 10.1016/j.paid.2018.07.007]

67. Sajjadi P, Hoffmann L, Cimiano P, Kopp S. A personality-based emotional model for embodied conversational agents: effects on perceived social presence and game experience of users. Entertainment Computing 2019 Dec;32:100313-100310. [doi: 10.1016/j.entcom.2019.100313]

68. Tammy Lin J, Bowman N, Lin S, Chen Y. Setting the digital stage: defining game streaming as an entertainment experience. Entertainment Computing 2019 Aug;31:1-8. [doi: 10.1016/j.entcom.2019.100309]

69. Oliver MB, Bowman ND, Woolley JK, Rogers R, Sherrick BI, Chung M. Video games as meaningful entertainment experiences. Psychology of Popular Media Culture 2016 Oct;5(4):390-405. [doi: 10.1037/ppm0000066]

70. Bonner D, Dorneich M. Developing game-based learning requirements to increase female middle school students interest in computer science. In: Proceedings of the Human Factors and Ergonomics Society Annual Meeting. 2016 Presented at: Human Factors and Ergonomics Society Annual Meeting; September 19-23; Washington, DC p. 380-384. [doi: $10.1177 / 1541931213601086]$

71. Halim L, Rahman N, Wahab N, Mohtar L. Factors influencing interest in STEM careers: an exploratory factor analysis. Asia-Pacific Forum on Science Learning and Teaching 2018;19(2):1-34.

72. Krapp A. Interest, motivation and learning: an educational-psychological perspective. Eur J Psychol Educ 1999 Mar;14(1):23-40. [doi: 10.1007/bf03173109]

73. Martin-Hansen L. Examining ways to meaningfully support students in STEM. Int J STEM Educ 2018 Dec 20;5(1):53. [doi: 10.1186/s40594-018-0150-3]

74. Guzey SS, Ring-Whalen EA, Harwell M, Peralta Y. Life STEM: a case study of life science learning through engineering design. Int J Sci Math Educ 2017 Oct 6;17(1):23-42. [doi: 10.1007/s10763-017-9860-0]

75. Beier ME, Rittmayer AD. Motivational factors in STEM: interest and self concept. In: Bogue B, Cady E, editors. Applying Research to Practice (ARP) Resources. Canada: ARP Resources; 2008:1-10.

76. Roberts T, Jackson C, Mohr-Schroeder MJ, Bush SB, Maiorca C, Cavalcanti M, et al. Students' perceptions of STEM learning after participating in a summer informal learning experience. Int J STEM Educ 2018 Sep 21;5(1):1-14. [doi: 10.1186/s40594-018-0133-4]

77. Mohd Shahali EH, Halim L, Rasul MS, Osman K, Zulkifeli MA. STEM learning through engineering design: impact on middle secondary students' interest towards STEM. EURASIA J Math Sci Tech Ed 2017;13(5):1189-1121. [doi: 10.12973/eurasia.2017.00667a]

78. Baxter J, Collins J. STEM education: creating meaningful experiences with interaction design. In: Reidsma D, editor. Intelligent Technologies for Interactive Entertainment. USA: Springer International Publishing; 2014:109-112.

79. Meaningful experiences in STEM learning make a difference!. Project Exploration. 2017. URL: https://projectexploration. org/2017/12/21/meaning-experiences-stem-learning-make-difference/ [accessed 2020-08-10]

\section{Abbreviations}

STEM: science, technology, engineering, and mathematics

Edited by G Eysenbach; submitted 21.05.20; peer-reviewed by C Gabarre, P Stourac; comments to author 15.06.20; revised version
received 09.10.20; accepted 24.10.20; published 19.02.21
Please cite as:
Ishak SA, Din R, Hasran UA
Defining Digital Game-Based Learning for Science, Technology, Engineering, and Mathematics: A New Perspective on Design and
Developmental Research
J Med Internet Res $2021 ; 23(2): e 20537$
URL: $\underline{\text { http://www.jmir.org/2021/2/e20537/ }}$
doi: $\underline{10.2196 / 20537}$
PMID: $\underline{33605885}$

CShahrul Affendi Ishak, Rosseni Din, Umi Azmah Hasran. Originally published in the Journal of Medical Internet Research (http://www.jmir.org), 19.02.2021. This is an open-access article distributed under the terms of the Creative Commons Attribution 
License (https://creativecommons.org/licenses/by/4.0/), which permits unrestricted use, distribution, and reproduction in any medium, provided the original work, first published in the Journal of Medical Internet Research, is properly cited. The complete bibliographic information, a link to the original publication on http://www.jmir.org/, as well as this copyright and license information must be included. 